\title{
PENGGUNAAN METODE DEMONSTRASI DAN MEDIA NYATA UNTUK MENINGKATKAN HASIL BELAJAR IPA TENTANG STRUKTUR AKAR PADA SISWA KELAS IV SDN 11 TEBATKARAI KABUPATEN KEPAHIANG
}

\author{
Emmi Susiyanti \\ SD Negeri 11 Tebat Karai
}

\begin{abstract}
Abstrak
Penelitian Tindakan Kelas ini bertujuan untuk mengetahui kelemahan yang dilakukan selama proses pembelajaran agar dapat mencari solusi pada pembelajaran. Subyek penelitian adalah siswa kelas IV SDN11 Tebat Karai yang berjumlah 11 siswa yang terdiri dari 3 siswa perempuan dan 8 laki-laki. Hasil penelitian awal ditemukan beberpa kelemahan selama proses pembelajaran yang dilakukan oleh guru yaitu: (1) kurangnya kemampuan murid dalam memahami materi pelajaran;(2) murid pasif dan berbicara sendiri;(3) nilai prestasi belajar IPA masih rendah; (4) Metode mengajar yamg digunakan guru masih cenderung ceramah;(5)kurangnya minat siswa dalam belajar; dan (6) kurangnya perhatian orang tua siswa terhadap belajar siswa. Dari keadaan diatas guru mencoba menerapkan metode "Demonstrasi dan menggunakan media nyata" dan membawa siswa kealam nyata.Hasil penelitian menunjukkan bahwametode demonstrasi dan media nyata dapat meningkatkan hasil belajar tentang struktur tumbuhan pembelajaran IPA kelas IV sekolah dasar
\end{abstract}

Kata kunci: Metode demonstrasi, Menentukan keberhasilan

\section{PENDAHULUAN}

Zaman globalisasi saat ini membuat persaingan semangkin ketat, penguasaan sains danteknologi adalah mutlak diperlukan. Melihat hal ini pemerintah mengeluarkan kebijakan dalam upaya meningkatkan mutu pendidikan untuk mengangkat mutu sumber daya manusia Indonesia khususnya guru melalui penyempurnaan kurikulum, perbaikan sarana dan prasarana, pelatihan guru, serta memperbaharuimetodepembelajaran.

Dalam pembelajaran diperlukan kesesuaian antara pengalaman guru dengan siswa, kebermaknaan pembelajaran IPA sangat ditentukan oleh kegiatan-kegiatan nyata, siswa SD belum dapat menghubungkan alasan yang bersifat hipotesis. Pengetahuan tumbuh kembang melalui pengalaman dan pemahaman. Semua akan berkembang semakin dalam dan kuat apabila selalu diuji dengan pengalaman baru.

Dalam hubungannya dengan uraian diatas Pembelajaran IPA pada umumnya masih dominan menggunakanmetode ceramah dan penugasan yang terkesan kaku dan dogmatis sehingga kurang memberikan kesempatan kepada siswa untuk berinteraksi dengan bendabenda konkrit. Selama ini siswa kurang diberi kesempatan untuk melakukan observasi, penyelidikan, memahami sendiri dalam melakukan eksperimen terhadap konsep-konsep sains melalui pengalaman nyata. Siswa tidak menyadari apa yang terjadi dan apa yang dialami disekitarnya mengandung konsep-konsep ilmiah yang dapat dipelajari melalui pelajaran IPA.

Belajar adalah sustu perubahan yang relatif permanen dalam suatu kecenderungan tingkah laku sebagai hasil dari praktek atau latihan. Hal senada diungkapkan pula Skinner dalam bukunya Dimyati dan Mujiono. Skinner berpandangan bahwa beajar adalah suatu perilaku pada saat orang belajar, maka responnya menjadi baik. Sebaliknya bila ia tidak belajar maka responya menurun (Mujiono2002:9). Dengan demikian belajar adalah merupakan perubahan perilaku individu atau seseorang yang disebabkan oleh latihanyang berkesinambungan.

Media merupakan alat atau saluran komunikasi. Media berasal dari bahasa latin dan 
merupakan bentuk jamak dari kata "medium" yang berarti perantara yaitu perantara sumber pesan dengan penerima pesan, dalam proses komunikasi biasanya guru berperan sebagai komunikator yang bertugas menyampaikan pesan/bahan ajar kepada siswa sedang siswa berperan sebagai penerima pesan, ketika guru menyampaikan pesan kepada siswa maka perlu wahana penyalur pesan yaitu media.

Salah satu media pembelajaran adalah media tiga dimensi yang digunakan dalam kegiatan pembelajaran diantaranya media realita. Media realita (benda-benda nyata) merupakan alat bantu visual dalam pembelajaran yang berfungsi memberikan pengalaman langsung kepada siswa.

Mengggunakan benda-benda nyata dalm pembelajaran IPA merupakan hal yang sangat dianjurkan, sebab siswa akan lebih memahami materi yang diajarkan. Untuk mengajarkan materi struktur tumbuhan dalam hal ini akar, maka guru menunjukkan akar yang sebenarnya. Hal ini akan memudahkan dalam pemahaman siswa terhadap materi pelajaran.

Metode demonstrasi merupakan metode mengajar yang menyajikan bahan pelajaran dengan menunjukkan secara langsung obyek atau cara melakukan sesuatu sehingga dapat mempelajarinya secara proses. Metode ini dapat digunakan pada smua pelajaran disesuaikan dengan topikdan tujuan pembelajaran yang akan dicapai. Dalam metode demonstrasi cenderung bahan dan situasi yang digunakan adalah obyek yang sebenarnya Anitah(2007:525).

Menurut Elizar(1996:45) keunggulan dari metode demonstrasi adalah kemungkinan siswa mendapat kesalahan lebih kecil, sebab siswa mendapatkan langsung dari hasil pengamatan kemudian mendapakan pengalaman langsung.

Usman(2002:46) menyatakan bahwa keunggulan metode demonstrasi adalah perhatian siswa akan dapat berpusat sepenuhnya pada pokokbahasan yang akan didemonstrasikan, sehingga dapat memberikan pengalaman praktis yang dapat membentuk ingatan yang kuat dan keterampilan dalam berbuat, menghindarkan kesalahandalam mengambil suatu kesimpulan.
Syaiful Bahri Djamara(2000:56) menyatakan keunggulan metode demonstrasi adalah membantuanak didik memahami dengan jelas jalannyasuatu proses atau kerja suatu kegiatan pembelajaran, mempermudah untuk menjelaskan berbagai kesalahan-kesalahan yang terjadi dari hasil ceramah dan dapat memperbaiki melalui pengamatan dan contoh konkret dengan menghadirkan obyek sebenarnya.

Dari ketiga pendapat diatas dapat disimpulkan bahwa keunggulan demonstrasi adalah siswa dapat memusatkan perhatiannya pada pokok bahasan yang akan didemonstrasikan. Siswa memperoleh pengalaman yang dapat membentuk ingatan yang kuat, siswa terhindar dari kesalahan dalam mengambil suatu kesimpulan. Pertanyaanpertanyaan yang timbul dapat dijawab sendiri oleh siswa pada saat dilaksanakan demonstrasi, apabila terjadi keraguan siswa dapat langsung bertanyakepada guru, dan kesalahan-kesalahan yang terjadi dari hasil ceramah dapat diperbaiki karena langsung memberikan contoh konkretnya.

Hasil belajar adalah perubahan keterampilan dan kecakapan, kebiasaan, sikap, pengertian pengetahuan, aspirasi yang dikenal dengan istilah kognitif, afektif, dan psikomotorik melalui perubahan belajar(Abror, 1993:65), sedangkan Hamalik menyatakan bahwa siswa dikatakan berhasil dalam belajarnya, apabila dapat mengembangkan kemampuan pengetahuan dan pengembangan sikap(Hamalik, 1990:97) Pada bagian lain Nawawi(1981:10) Mengemukakan bahwa hasil belajar dapat diartikan sebagai tingkat keberhasilan siswa dalam mempelajari materi pelajaran di sekolah yang dinyatakan dalam skor yang diperoleh dari hasil tes mengenai sejumlah materi pelajaran tertentu(Alwasilah,2000:90-91)

Beberapa pendapat tersebut menunjukkan bahwa hasil belajar adalah salah satu hasil ujian dalam proses pengajaran yang dilakukan secara formal. Tingkat keberhasilan siswa dalam menguasai pelajaran di sekolah dinyatakan dengan simbol, angka, atau huruf dalam rapor dan diperoleh dari hasil tes mengenai sejumlah materi pelajaran tertentu. Pengukuran hasil 
belajar siswa diukur dari waktu ke waktu dan merupakan gabungan dari aspek sikap, pengetahuan, dan keterampilan.

Berdasarkan hasil observasi dan informasi yang diberikan oleh guru di SD Negeri 11 Tebat Karai Kab.Kepahiang, khususnya kelas IV terdapat permasalahan yang dihadapi oleh siswa yaitu rendahnya nilai ulangan harian, pernyataan tersebut didasarkan pula pada hasil nilai ulangan harian siswa pada mata pelajaran IPA yang cukup rendah dan daya serap siswa secara klasikal masih dibawah standar minimum yaitu $65 \%$. Secara rinci dari 11 siswa kelas IV di SDN11 Tebat Karai yang mendapat nilai 70 adalah 1 siswa $(9,10 \%)$, yang mendapat nilai 60 sebanyak 5 siswa $(45,45 \%)$, yang mendapat nilai50 sebanyak 5 siswa $(45,45 \%)$. Fakta ini menunjukkan bahwa siswa SD Negeri 11 Tebat Karai belum mencapai ketuntasan belajar pada mata pelajaran IPA, atas dasar permasalahan tersebut peneliti menganggap perlu dilakukan penelitian agar menemukan solusi untuk mengatasi permasalahan tersebut.

\section{METODE}

Penelitian ini adalah penelitian Tindakan Kelas dengan menggunakan metode deskriptif.Pengumpulan data yang dilakukan dalam penelitian ini adalah berupa data kualitatif. Metode yang digunakan untuk pengumpulan data pada penelitian ini adalah sebagai berikut. Metode observasi (Purwanto, 1985:150) dilakukan sebelum kegiatan yaitu sebagai pengumpulan data observasi awal, serta pada saat siklus berlangsung.Objek penelitian ini adalah kegiatan siswa dan guru kelas IV SD Negeri 11 Tebat Karai .

Analisis Data dalam penelitian ini adalah deskriptif kualitatif. Analisis deskriptif kualitatifmerupakan analisis yang menggambarkan keadaan yangada lapangan disertai dengan fakta-fakta yang ada. Dalam analisis data ada beberapa tahap yang dilakukan peneliti, yaitu: (a) Reduksi data, yaitu proses penyeleksian, pengelompokan dan pengorganisasian data mentah; dan (b) Deskripsi data yaitu proses penyusunan hasil dari reduksi data untuk menampilkan data secara jelas dan mudah untuk dimengerti baik dalam bentuk narasi, tabel maupun grafik.

Penarikan kesimpulan dari analisis dan sintesis. Analisis dilakukandengan memikirkan kendali yang menyebabkan munculnya sesuatu yang diharapkan atau tidak diharapkan. Analisis data hasil observasi selama proses pembelajaran berlangsung berupa deskriptif kualitatif.

Dalam pelaksanaan observasi peneliti dibantu oleh observer untuk mengisi daftar ceklist lembar observasi yang telah dipersiapkan.Adapun aspek yang diobservasimeliputi keaktifan siswa dalam memperhatikan dan mendengarkan penjelasan guru, bertanya, menjawab dan mengemukakan pendapat, serta kegiatan dalam pembelajaran dengan menggunakan metode demonstrasi.

\section{HASIL}

Dalam hal ini hasil ini akan dipaparkan hasil penelitian dan pembahasan IPA tentang materi Struktur akar, dengan menggunakan metode demonstrrassi pada siswa kelas IV SD Negeri 11 Tebat Karai. Hasil penelitian meliputi tes evaluasi siswa pada siklus 1 dan siklus 2, serta hasil penilaian proses yang dilakukan selam berlangsungnya proses belajar- mengajar.

\section{Tabel I}

Nilai sebelum perbaikan

\begin{tabular}{|c|c|}
\hline Jumlah siswa & Nilai \\
\hline- & $\mathbf{8}$ \\
\hline 1 & 7 \\
\hline 5 & 6 \\
\hline 5 & 5 \\
\hline- & 4 \\
\hline Rata-rata & $\mathbf{6 , 0 9}$ \\
\hline
\end{tabular}

Presentase ketuntasan 54,55 \% , karena yang berhasil mendapat nilai 6 keatasada 6 dan 5 siswa masih dibawah 6,maka pembelajaran masih dikatakan belum tuntas, karena pembelajaran dikatakan tuntas jika yang mendapat nilai $\geq 6$ mencapai $70 \%$ maka perlu dilakukan perbaikan siklus 1 . 
Tabel II Siklus I

\begin{tabular}{|c|c|}
\hline Jumlah siswa & Nilai \\
\hline $\mathbf{1}$ & $\mathbf{8}$ \\
\hline $\mathbf{1}$ & $\mathbf{7}$ \\
\hline $\mathbf{5}$ & $\mathbf{6}$ \\
\hline 4 & $\mathbf{5}$ \\
\hline- & 4 \\
\hline
\end{tabular}

Dilihat pada tabel diatas yang mendadapat nilai 6 keatas berjumlah 7 siswa atau $63,64 \%$, yang belum berhasil 4 siswa atau 36,36 \%,maka perlu perbaikan. Perbaikan dilakukan pada siklus 2.

Pada siklus 2 perbaikan dilakukan dengan menerapkan metode demonstrasi dan menggunakan media nyata hasilnya dapat dilihat pada tabel berikut.

Tabel III siklus 2

\begin{tabular}{|c|c|}
\hline Jumlah siswa & Nilai \\
\hline $\mathbf{1}$ & $\mathbf{8}$ \\
\hline $\mathbf{5}$ & $\mathbf{7}$ \\
\hline $\mathbf{4}$ & $\mathbf{6}$ \\
\hline $\mathbf{1}$ & $\mathbf{5}$ \\
\hline- & $\mathbf{4}$ \\
\hline
\end{tabular}

Dilihat pada tabel diatas yang tidak mencapai nilai 6 hanya 1 siswa atau $8,33 \%$ sedang yang mendapat nilai 6 keatas ada 10 siswa atau 91,67\%,hal ini menunjukkan peningkatan yang signifikan dan saat proses pembelajaran berlangsung, keaktifan siswa sangat terlihat walaupunmasih ada satu siswa yang tidak tuntas, hal ini dikarenakan memang kemampuan berfikir siswa tersebut rendah khususnya dalam ranah kognitif.

Berdasarkan pada analisis data diatas diperoleh bahawa minat siswa pada pembelajaran IPA kelas IV SD Negeri 11 Tebat Karai khususnya tentang materi Struktur tumbuhan dengan menggunakan metode demonstrasi serta siswa dibawa pada dunia nyata atau alam sekitar hasil belajar siswa semakin meningkat ini membuktikan bahwa pembelajaran dengan menggunaan metode demonstrasi dan media nyata dapat diterapkan pada pembelajaran tentang struktur tumbuhan pembelajaran IPA kelas IV sekolah dasar.

\section{SIMPULAN}

Penggunaan Media dan metode yang tepatsangatberpengaruh terhadap pemahaman konsep pada pembelajaran IPA khususnya materi struktur akar karena dapat menghilangkan kejenuhan dalam pembelajaran dan menumbuhkan rasa senang, rasa percaya diri, dan memiliki keberanian. Terbukti dengan menggunakan metode dan pendekatan tersebut siswa dapat memahami konsep karena siswa mengaami dan mempraktekan langsung melalui media nyata siswa akan mudah mengingat peristiwa yang telah dialami.

\section{SARAN}

Metode demonstrasi dan media nyata dapat dikembangkan pada pembelajaran pembelajaran lain. Peningkatan dan hasil belajar siswa hendaknya tidak terbatas pada metode demonstrasi karena masih banyak media dan metode yang lain yang dapat dipakai, hendaknya guru selalu dapat menggunakan atau memilih media dan meode yang sesuai dalam pembelajaran.

\section{DAFTAR PUSTAKA}

Anitah, Sri. 2007.Strategi pembelajarandi $S D$,Jakarta: Universitas terbuka.

Arikunto. 2006.Metode Dokumentasi. Jakarta: Bina Aksara.

Elizar. 1996.Metode Demonstrasi dalam Pembelajaran.Jakarta: Erlangga.

Mujiono. 2002. Belajar dan Pembelajaran. Jakarta: Rineka Cipta.

Nawawi. 1981.Hasil Belajar Siswa. Bandung: Pustaka Martina.

Purwanto. 1985.Metode Observasi: Jakarta: Angkasa Jaya.

Djamarah, SyaifulBahri. 2000.Kegunaan Metode Demonstrasi dalam Pembelajaran.Jakarta Rineka Cipta.

Usman, Basyirudin. 2002.Metode Demonstrasi dan Pembelajaran. Jakarta: Erlangga. 